\title{
TSETSE ELIMINATION: ITS INTEREST AND FEASIBILITY IN THE HISTORICAL SLEEPING SICKNESS FOCUS OF LOOS ISLANDS, GUINEA
}

\author{
KAGBADOUNO M.*, CAMARA M.*, BOUYER J.**, HERVOUET J.P.***, COURTIN F.****, \\ JAMONNEAU V.****, MORIFASO O.******, KABA D.******* \& SOLANO P.******
}

\section{Summary:}

Guinea is the West African country which is currently the most prevalent for sleeping sickness. The littoral area is the region where most of the recent sleeping sickness cases have been described, especially the mangrove sleeping sickness foci of Dubreka and Boffa where Glossina palpalis gambiensis is the vector. Loos islands constitute a small archipelago $5 \mathrm{~km}$ apart from the capital, Conakry. Medical, animal, and entomological surveys were implemented in these islands in Oct-Nov 2006. No pathogenic trypanosomes were found in these surveys. The locally very high tsetse densities (up to more than 100 tsetse/trap/day) linked to pig rearing, constitute a high potential risk for humans ltaking into account populations movements with neighboring active sleeping sickness foci of the Guinea littoral, and the history of sleeping sickness on these islands), and for the economically important pig rearing, as well as a danger for tourism. This situation, associated to the possibility of elimination of these tsetse populations due to low possibility of reinvasion, led the National Control Program to launch a tsetse elimination project following an "area wide" strategy for the first time in West Africa, which participates in the global objective of the PATTEC (Pan African

Tsetse and Trypanosomosis Eradication Campaign).

KEY WORDS : Glossina palpalis gambiensis, elimination, pig, sleeping sickness, Guinea.
Résumé : ÉlIMINATION DES MOUCHES TSÉ-TSÉ : INTÉRÊT ET FAISABILITÉ DANS L'ANCIEN FOYER DE MALADIE DU SOMMEIL DES ÎLES DE LOOS EN GuinÉE

La Guinée est actuellement le pays d'Afrique de l'Ouest le plus touché par la maladie du sommeil, en particulier la région littorale des mangroves où le vecteur est Glossina palpalis gambiensis, notamment au niveau des foyers de Dubréka et Boffa. Les iles de Loos constituent un petit archipel à $5 \mathrm{~km}$ de la capitale Conakry. Au cours des enquêtes épidémiologiques menées sur les vecteurs, les hôtes humains et animaux en octobre-novembre 2006, nous n'avons pas mis en évidence de trypanosomes pathogènes. Toutefois, les fortes densités de tsé-tsé ljusqu'à plus de 100 mouches/piège/jour), associées spatialement aux élevages de porcs, constituent un véritable risque pour les humains au vu des nombreux mouvements de populations entre ces iles et les foyers voisins de mangrove, ainsi qu'au vu de l'historique de la maladie du sommeil sur ces îles. Il existe également un fort risque de trypanosomose pour l'activité d'élevage de porcs. Enfin, ces iles constituent l'un des principaux lieux touristiques de la région. Cette situation, combinée à la possibilité d'une élimination définitive, a conduit le Programme national de lutte contre la trypanosomose humaine africaine à envisager pour la première fois en Afrique de l'Ouest un programme d'élimination des tsé-tsé de ces îles, basé sur une stratégie "area wide", ce qui participe à l'objectif global de la PATTEC (Campagne panafricaine d'éradication des tsé-tsé et des trypanosomoses).

MOTS CLÉS : Glossina palpalis gambiensis, élimination, porc, maladie du sommeil, Guinée.

especially in this littoral area. Loos islands constitute a small archipelago $5 \mathrm{~km}$ apart from the capital, Conakry, where tsetse (G. p. gambiensis) occurr and are well known by the inhabitants. HAT cases have been reported since the 1940s from all the three inhabited islands. There are many domestic animals in the islands, including many pigs which are known to constitute an important blood feeding source for G. palpalis, and which are considered as a reservoir for sleeping sickness (Gibson et al., 1978).

Finally, Loos islands harbour tsetse, domestic animals, a human population that has many exchanges with the neigboring sleeping sickness foci of the littoral (Dubreka, Boffa): there is therefore a high risk of human and animal trypanosomoses. Hence a medical, an animal, and an entomological survey were implemented all together at the same period (October-November 2006, just at the end of the rainy season) to constitue the 
baseline data survey for tsetse elimination on these islands. The Guinean National Control Program of HAT wants to implement this tsetse elimination campaign mainly because of:

- presumed technical feasibility due to the small total area to be treated (around 15 sq. km), and genetic isolation of these tsetse compared to their continental counterpart (Camara et al., 2006), which will allow to follow an "area wide" strategy of elimination (Vreysen et al., 2007). This kind of elimination strategy presupposes to address the targeted tsetse as a whole, unique and isolated population to ensure no possibility of reinvasion during the control and elimination phases which must follow a sequential organisation. Previous unsuccessful attempts to eliminate tsetse may be due to the non respect of this criteria (e.g. de la Rocque et al., 2001). The only successful tsetse elimination campaign so far has thus been the elimination of $G$. austeni in Zanzibar in East Africa (Vreysen et al., 2000);

- the possibility of a sustainable prevention of the populations from sleeping sickness if the vector is eliminated, and also as a support to the economic activity of pig rearing, which may be threatened by animal trypanosomosis;

- the possibility of protecting the important touristic activity of these islands since they are frequented by many people from Conakry and by european tourists also; - the fact that if successful, this would be the first time in West Africa that tsetse would be eliminated from a sleeping sickness area;

- last but not least, the pedagogical dimension of this project which will thus train a national team to entomological surveys, control methods, and the rigour needed to reach this ambitious objective.

\section{MATERIAL AND METHODS}

\section{STUDY AREA}

The Loos islands constitute a small archipelago off the coast of Guinea Conakry, West Africa. The two largest islands - Fotoba (also known as Tamara) and Kassa - are about $10 \mathrm{~km}$ long and rarely more than $1 \mathrm{~km}$ width, with maximum altitude at 162 masl. The nearest to the mainland (Kassa) is about $4-5 \mathrm{~km}$ from the Kaloum peninsula of Conakry (see map in Fig. 1). Three of the five islands are inhabited (Fotoba, Kassa and Room), mainly involved agriculture (manioc, palm trees, mangoes), fishing, pig
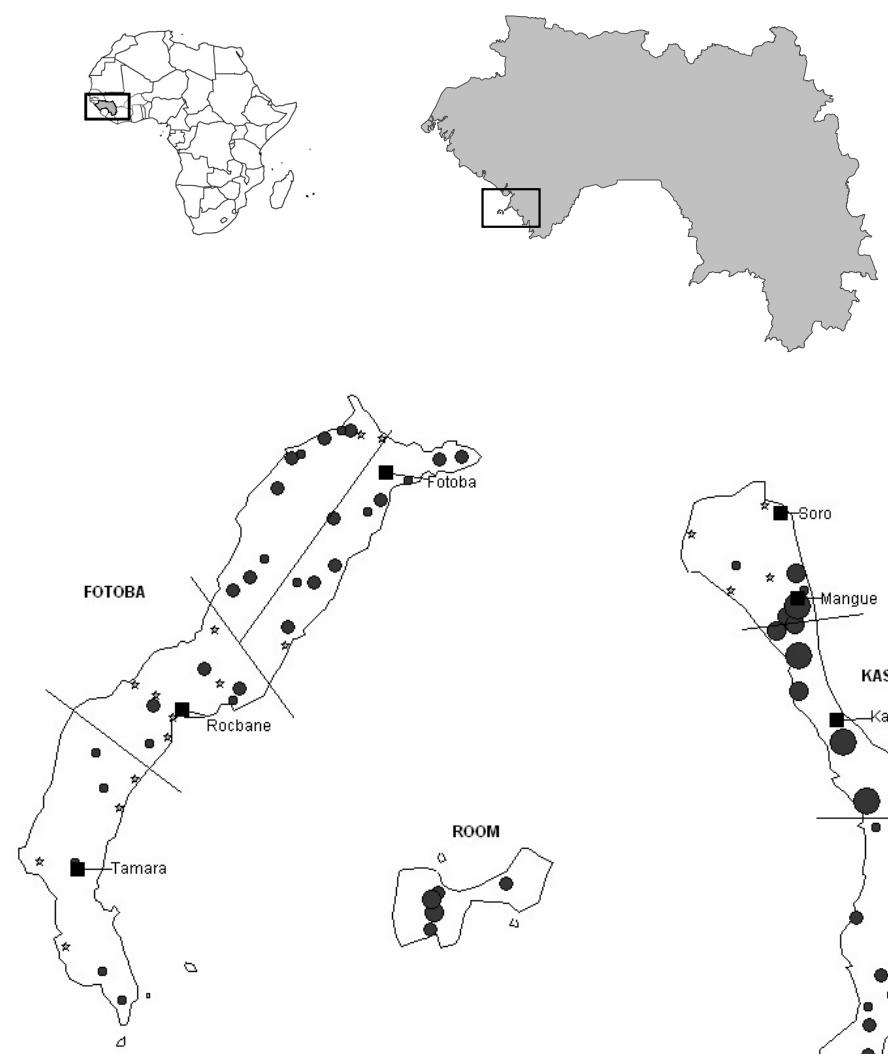

0 $2.5 \mathrm{~km}$

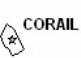

Fig. 1. - Geographic location of study area and apparent density of G. p. gambiensis on Loos Islands.

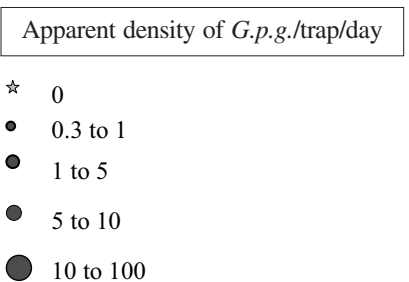


breeding, tourism, although bauxite mining was also important during 1950-70. Pig breeding constitutes an important secondary economic activity in Kassa; pigs are generally sold and sent to Conakry. The vegetation is constituted of anthropised shrub Guinean savannah on the rocky areas, secondary forests in the fallow areas and vergers of palms (Elaeis guineensis) and mango trees; annual rainfall is around $4,000 \mathrm{~mm}$.

\section{ENTOMOLOGICAL SURVEY}

76 Vavoua traps (Laveissière \& Grébaut, 1990) were settled, cages were collected daily during 3-4 days to assess apparent densities of tsetse (ADT) and sex ratio. Tsetse that were still alive were dissected to determine their trypanosome infection rates. Mouthparts, midguts and salivary glands were microscopically examined. When flies were engorged, bloodmeals were collected on Whatman filter paper to know the bloodmeal source using PCR heteroduplex (Njiokou et al., 2004).

\section{SLEEPING SICKNESS SURVEY}

Prior to the medical survey, an exhaustive census of all the resident population was undertaken, taking into account the sex and age of the population. This allows knowing what part of the population has really been surveyed.

The HAT diagnostic procedure in the field was performed according to the World Health Organisation (WHO) and HAT National Control Program recommendations. Briefly, people were first screened using the Card Agglutination Test for Trypanosomiasis (CATT) on whole blood (Magnus et al., 1978). CATT whole blood seropositives were tested subsequently in CATT on plasma (Magnus et al., 1978). Parasitological tests (mAECT which is the mini anion exchange column technique Lumsden et al., 1979, and direct examination of lymph node aspirate) were only performed on the subjects positive to CATT on plasma or harbouring adenopathies.

\section{ANIMAL TRYPANOSOMOSIS SURVEY}

All domestic animals were counted after having explained the objectives to their owners. Specifically for pigs, all pig pens were exhaustively censed and georeferenced with the help of the National Direction of Elevage using a global positioning system (GPS). Within each type of domestic animals (pigs, goats, sheep), animals were randomly sampled. After bleeding (jugular vein), the pack cell volume (PCV) was determined and the parasitological diagnosis was performed using the Buffy coat technique (BCT, Murray et al 1977).

\section{STATISTICS}

Since ADT distributions are generally not normal but aggregated (Bouyer 2006; Bouyer et al. 2006), the cor- relations between tsetse average densities and the total number of pigs in buffers of 100, 200, 500 and 1,000 m around the traps were investigated at the trapping site level using Kendall's rank correlation tau (Hollander \& Wolfe, 1973). It was not possible to test greater distances because of the spatial shape of the islands (generally $<1 \mathrm{~km}$ width).

\section{RESULTS}

\section{ENTOMOLOGICAL SURVEY}

\section{Trapping}

total of 638 tsetse were caught, all belonging to the G.p. gambiensis subspecies. Apparent 1 densities were very heterogeneous (ranging from 0 to a max of 101 flies/trap/day), and were lower in Fotoba (0.80/trap/day, s.d. 0.83) compared to Kassa (7.05/trap/day, s.d. 20.94) (Student $t$ test, $\mathrm{p}<$ 0.05) (Fig. 1). In Kassa, locally high densities of tsetse (from 20 to more than 100/trap/day) were found, always in traps located near pig pens (Fig. 2).

On Kassa, a total of 259 males and 273 females were caught (total 532 , sex ratio $\mathrm{M} / \mathrm{F}=0.95$ ), whereas on Fotoba, 60 males and 46 females were caught (total 106 , sex ratio $\mathrm{M} / \mathrm{F}=1.30$ ).

Out of 150 dissected tsetse (80 in Fotoba and 70 in Kassa), none were found infected with trypanosomes in neither of the organs dissected and checked micro-

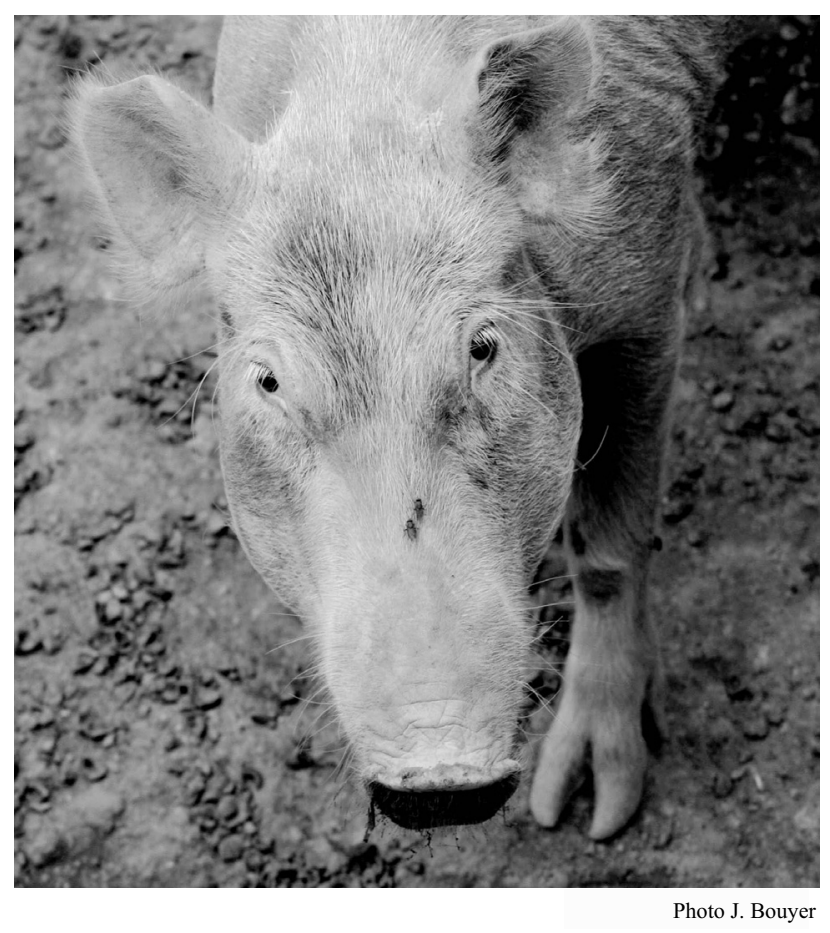

Fig. 2. - Photo showing a local pig harbouring three tsetse flies (2 on the snout and 1 on the left forelimb). 


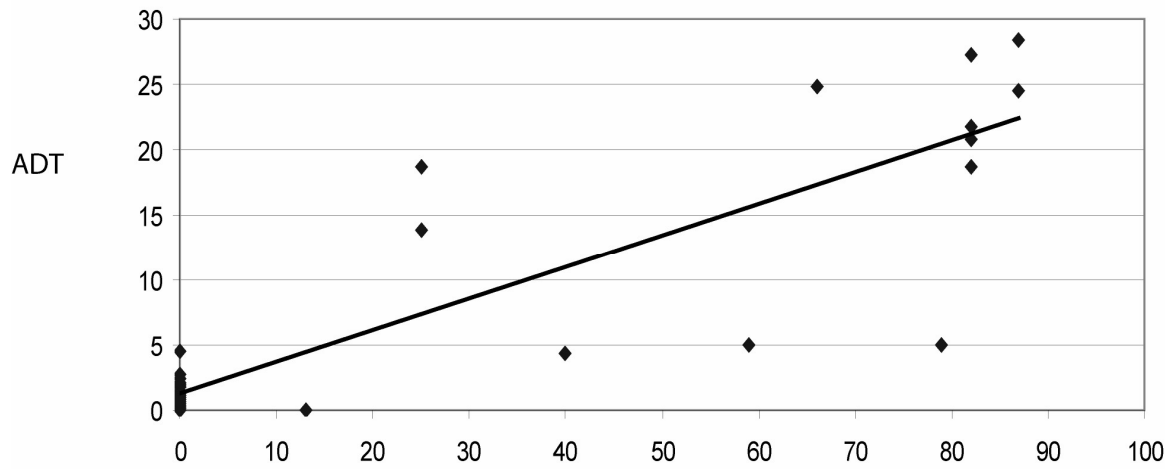

Fig. 3. - Correlation between G.p. gambiensis apparent densities (ADT) and pig densities in $500 \mathrm{~m}$ buffers around the traps $(\tau=0.5356694, \mathrm{z}=5.8563, \mathrm{p}$ value $=4.734 \mathrm{e}-09)$

Number of pigs in 500m-buffers around the traps

scopically. In Fotoba, the dissection effort represented $75 \%$ of the collected flies, whereas it was only $13 \%$ on Kassa.

We were able to analyse three tsetse bloodmeals, all coming from Kassa, of which two came from pigs and one from human.

Correlation with pig densities

Tsetse ADT were significantly correlated to the total number of pigs in the neighbouring of the traps, and the linear correlation was the best for $500-1000 \mathrm{~m}$ $(100 \mathrm{~m}: \tau=0.3839802 \mathrm{z}=3.9571, \mathrm{p}$-value $=7.585 \mathrm{e}-$ $05 ; 200 \mathrm{~m}: \tau=0.3793654, \mathrm{z}=4.0024, \mathrm{p}$-value $=6.27 \mathrm{e}-$ $05 ; 500 \mathrm{~m}: \tau=0.5356694, \mathrm{z}=5.8563$, p-value $=4.734 \mathrm{e}-$ 09; $1,000 \mathrm{~m}: \tau=0.5632884, \mathrm{z}=6.3275, \mathrm{p}$-value $=$ 2.492 e-10) (Fig. 3).

\section{SLEEPING SICKNESS SURVEY}

A total of 6,195 people were counted in June 2006 (3,333 on Kassa, 2,298 on Fotoba, and 564 on Room). From these, 4,361 (70 \%) had a digital blood puncture to look for HAT. Sex ratio (males/females) of the people counted during the census was 1.02 , it was 0.9 on the people present at the survey. The part of the population who was the more present at the survey was the children, whereas men of the active part (between 15 to 50 old) were the least present ( $47 \%$, Table I).

Two subjects (from Kassa) were found positive with CATT on whole blood, but were not confirmed with

\begin{tabular}{lccc}
\hline & Men & Women & Total \\
\hline Less than 15 old & $85 \%$ & $83 \%$ & $84 \%$ \\
15 to 50 & $47 \%$ & $70 \%$ & $58 \%$ \\
More than 50 & $67 \%$ & $84 \%$ & $75 \%$ \\
Total & $64 \%$ & $76 \%$ & $70 \%$ \\
\hline
\end{tabular}

From the census made before the medical survey, the proportion $(\%)$ of each age and sex category who was present at the medical survey was registered and shown here.

Table I. - Proportion of population visited by the medical survey regarding age and sex. the more specific CATT on plasma; therefore these subjects probably presented a cross-reaction.

\section{ANIMAL TRYPANOSOMOSIS SURVEY}

The census of domestic animals on the islands revealed the presence of 1,600 pigs (among which $90 \%$ were on Kassa), 50 cattle on Fotoba and 5 in Kassa, 1,400 goats, 2,850 sheep. The presence of few monkeys and monitor lizards was also noticed.

A total of 155 animals were sampled, among which 55 pigs, 50 goats and 50 sheep. Mean PCV values in pigs were 38 (with standard deviation s.d. of 3.25) in Fotoba, and 32.5 (s.d. 7.01) in Kassa, this latter value being significantly lower (Student $t$ test, $\mathrm{p}<0.05$ ). PCV values were 24.9 (s.d. 3.57) and 28.9 (s.d. 7.29) respectively for goats (no significant difference, Table II). Sheep (only sampled in Kassa) had a mean PCV of 23.66 (s.d. 5.45).

The BCT was performed on a total of 104 animals ( 55 pigs, 50 goats and 5 sheep), among which none was found infected with trypanosomes.

\begin{tabular}{lccc}
\hline & Pigs & Sheep & Goat \\
\hline Mean & 33.29 & 23.66 & 28.10 \\
S.d. & 6.86 & 5.45 & 6.88 \\
Min. & 14 & 15 & 17 \\
Max. & 47 & 41 & 47 \\
Median & 35 & 23 & 27 \\
\hline
\end{tabular}

Mean values of the packed cell volume (PCV) regarding animal species sampled, together with its standard deviation (S.d.), minimum (Min) and maximum (Max) values, and median.

Table II. - Packed cell volume values measured on animals on Loos islands.

\section{DISCUSSION}

$\mathrm{V}$ Tery little is known on the bio ecology of tsetse in the littoral areas of West Africa including mangrove habitat. The distribution pattern and 

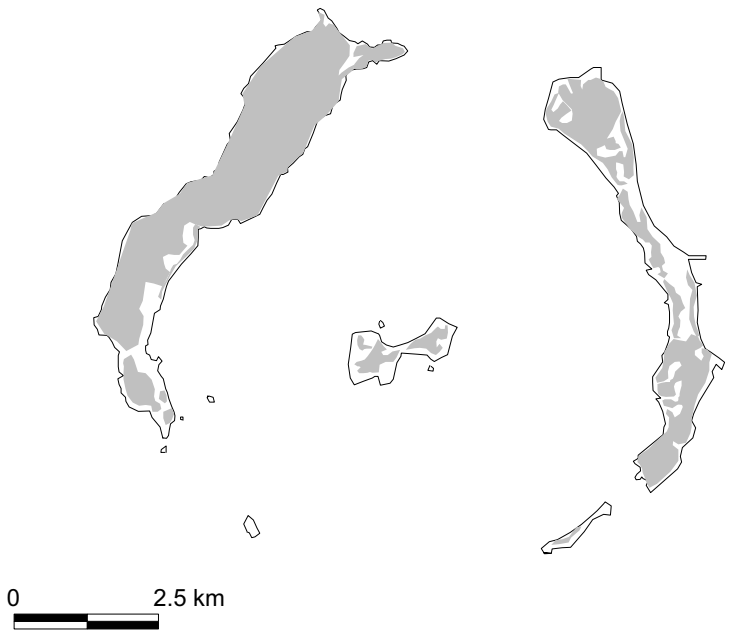

$\Delta$
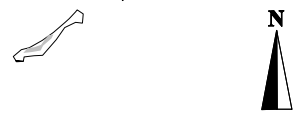

Fig. 4. - Distribution of the favourable habitats for G. p. gambiensis on Loos islands (obtained from Landsat 7TM interpretation).

ecology of G.p. gambiensis on Loos islands is very different from what is known in the West African humid savannah area, where they are mainly found in the riverine vegetation (Buxton, 1955; Bouyer et al., 2005). Here, they show a two dimensional distribution versus a linear distribution in the humid savannah areas (Bouyer, 2006). During the dry season, tsetse appeared to be limited to the secondary forests, palm and mango-trees plantations which represented $72 \%$ of the total surface (10.72 sq.km vs 14.83 sq.km) (Fig. 4). During the rainy season, tsetse may be found almost everywhere, with a relative hygrometry superior to $60 \%$, even in the drier areas.

A linear correlation between tsetse ADT and pig densities was evidenced; it was better for the greater distances, suggesting an overall increase of tsetse populations thanks to an increase of adult feeding resource. Pigs are therefore higly likely to provide the most important feeding source, and are suspected to be responsible for the significantly higher tsetse density found on Kassa compared to Fotoba. It is to be mentioned that humans may also provide an important bloodmeal source since they reported us they consider the biting of tsetse as a very important nuisance.

Active men were the least present during the parasitological survey, which may be important due to the tendancy of sleeping sickness to affect more men than women. Actually, it has been reported that when $75 \%$ of the total population is visited in a sleeping sickness survey, $50 \%$ of the patients are not detected because they were not present at the survey (Hervouët, 1983). The results of the medical survey suggest that Sleeping sickness may not be currently endemic on Loos islands, as compared to other current sero-prevalence records in West Africa (e.g. Solano et al., 2003), even in other parts of Guinea (Camara et al., 2005), although some historical cases were reported on these islands between
1940 and the 80s. However Sleeping sickness may still be imported at any time by population movements between the islands and the continent. At the same time, a prevalence of $1 \%$ has been reported in the focus of Dubreka (M. Camara, com. pers.), only $30 \mathrm{~km}$ apart from Loos Islands.

Pigs have been shown to harbour T. brucei gambiense (T. b. g.) in many Sleeping Sickness foci in Ivory Coast, Liberia (Gibson et al., 1978), and have been recently shown to be heavily infected with human (T.b.g.) and animal (T. congolense-forest type, T.c.f.) trypanosomes in Ivory Coast (Jamonneau et al., 2004). Pigs may then act as a reservoir for sleeping sickness with $T . b . g$. although this remains controversial, but may also be the victim of $T$. simiae (Hoare, 1972), which is very pathogenic for pigs, and which has been found in G. $p$. gambiensis (Solano et al., 1996). The fact that pigs from Kassa had a lower PCV value than those from Fotoba may be due to a parasitic disease or to other factors. PCV values found in pigs of our samples fall into the expected range of normal PCV values (Schalm et al., 2005).

Thanks to the human and animal censes made and discussions with people, we understood that pig breeding activity began around the 1980s in Kassa. We thus think that the very high tsetse densities found on Kassa and associated to pig breeding, may be quite a recent phenomenon. If we accept that the tsetse present are competent, this situation, which associates high densities of tsetse (up to 100/trap/day close to pig pens), and presence of pigs and humans, is potentially epidemic in case of introduction of a pathogenic trypanosome: it is thus a very serious threat to the health and animal sectors. The potential spread of the sleeping sickness on the islands would have disastrous consequences on both the public health of people and their economic situation, especially regarding pig breeding and tourism (these islands represent the most visited area close to Conakry by residents and tourists). This situation, associated to the possibility of elimination of these tsetse populations (Camara et al., 2006), had just lead the Guinean National Control Program to launch for the first time in West Africa a tsetse elimination project on these islands following an "area wide" strategy, which participates in the global objective of the PATTEC (Pan African Tsetse and Trypanosomosis Eradication Campaign initiated by the African Union). Taking into account the present epidemiological results, the vector control measures that will be applied during the suppression campaign may include: - pig treatment by epicutaneous insecticide at a monthly frequency, and the complementary use of impregnated mosquito nets around the pig pens;

- impregnated screens and traps in the favourable landscapes (reaching a density of 30 insecticide targets/sq km); 
- selective insecticide groundspraying on the denser secondary forests areas which may represent refugees for tsetse in the hot dry season.

We think that the present study in Loos islands, which has shown here that elimination could be contemplated, will constitute an example of broader interest for other places where different strategies to control African Trypanosomoses may occur and may be chosen according to different factors.

\section{ACKNOWLEDGEMENTS}

W e are indebted to the Ministry of Health and the Ministry of Agriculture and Livestock of the Republic of Guinea. We acknowledge the support of LTTRN through international collaboration, the support of SCAC Conakry and FSP "REFS", INCO-DEV "TFCASS" project $\mathrm{n}^{\circ}$ 031849, IRD Representation, WHO, and the involvement of VestergaardFrandsen and Bayer companies. We are grateful to the direction of CIRDES and IPR for their collaboration. Special thanks to Wilfried Yoni and Cene Bila (CIRDES), Fabien Dofini and Bamoro Coulibaly (IPR), Laure Guerrini (GIS analyses).

\section{REFERENCES}

Bouyer J., Guerrini L., César J., de la Rocque S. \& Cuisance D. A phyto-sociological analysis of the distribution of riverine tsetse flies in Burkina Faso. Medical and Veterinary Entomology, 2005, 19, 372-378.

Bouyer J., Guerrini L., Desquesnes M., De la Rocque S. \& CuiSANCE D. Mapping African Animal Trypanosomosis risk from the sky. Veterinary Research, 2006, 37, 633-645.

BOUYER J. Écologie des glossines du Mouhoun au Burkina Faso : intérêt pour l'épidémiologie et le contrôle des trypanosomoses africaines : Parasitologie. PhD thesis, 2006, Univ. Montpellier II.

BuxTon P.A. The natural history of tsetse flies. An account of the biology of the genus Glossina (Diptera). Lewis H.K. \& Co. Ltd, London, UK, 1955.

Camara M., Kaba D., Kagbadouno M., Sanon J.R., Ouendeno F. \& SOlano P. La trypanosomose humaine africaine en zone de mangrove en Guinée : caractéristiques épidémiologiques et cliniques de deux foyers voisins. Médecine Tropicale, 2005, 65, 155-161.

Camara M., Caro-Riano H., Ravel S., Dujardin J.P., Hervouet J.P., de Meeüs T., Kagbadouno M., Bouyer J. \& Solano P. Genetic and morphometric evidence for population isolation of Glossina palpalis gambiensis from Loos islands, Guinea. Journal of Medical Entomology, 2006, 43, 853860.

de la Rocque S., Augusseau X., Guillobez S., Michel V., De Wispelaere G., Bauer B. \& Cuisance D. The changing distribution of two riverine tsetse flies over 15 years in an increasingly cultivated area of Burkina Faso. Bulletin of Entomological Research, 2001, 91, 157-166.

Gibson W.C., Mehlitz D., Lanham S. \& Godfrey D.G. The identification of Trypanosoma brucei gambiense in liberian pigs and dogs by resistance to human plasma. Tropical Medicine and Parasitology, 1978, 29, 335-345.

Gouteux J.P., Laveissière C. \& Boreham P.F.L. Écologie des glossines en secteur pré-forestier de Côte d'Ivoire. 2. Préférences trophiques de Glossina palpalis s.l. Cahiers ORSTOM, 1982, sér. Ent. méd. et Parasitol., XX, 3-18.

HeRVouËT J.P. Systèmes d'occupation du sol, conditions sociales et transmission de la trypanosomiase humaine. Rapport OMS-TDR, 1983, ORSTOM Petit Bassam, document multigraphié, $104 \mathrm{p}$.

HoAre C.B. The trypanosomes of mammals. A zoological monograph. Blackwell Scientific Publications, Oxford, UK, 1972.

Hollander M. \& Wolfe D.A. Non parametric statistical inference. John Wiley \& Sons, New York, 1973.

Jamonneau V., Ravel S., Koffi M., Zeze D.G., Kaba D., N’Dri L., Coulibaly B., Cuny G. \& Solano P. Mixed trypanosome infections in tsetse and pigs and their epidemiological significance in a sleeping sickness focus in Côte d'Ivoire. Parasitology, 2004, 129, 693-702.

LAVEISSIÈRE C. \& GRÉBAuT P. Recherches sur les pièges à glossines. Mise au point d'un modèle économique : le piège "Vavoua". Tropical Medicine and Parasitology, 1990, 41, 185-192.

Lumsden W.H.R., Kimber C.D., Evans D.A. \& Doig S.J. Trypanosoma brucei: miniature anion-exchange centrifugation technique for detection of low parasitaemias: adaptation for field-use. Transactions of the Royal Society of Tropical Medicine and Hygiene, 1979, 73, 312-317.

Magnus E., Vervoort T. \& Van Meirvenne N. A card-agglutination test with stained trypanosomes (CATT) for the serological diagnosis of T. b. gambiense trypanosomiasis. Annales de la Société belge de Médecine Tropicale, 1978, 58, 169-176.

Murray M., Murray P.K. \& McInTYRe W.I.M. An improved parasitological technique for the diagnosis of African Trypanosomiasis. Transactions of the Royal Society of Tropical Medecine and Hygiene, 1977, 71, 325-326.

Nitokou F., Simo G., Mbida M.A., Truc P., Cuny G. \& Herder S. A study of host preference in tsetse flies using a modified heteroduplex PCR-based method. Acta tropica, 2004, 91, 117-120.

SChalm O.W., JaIN N.C. \& CAROLL E.C.J. Veterinary Hematology. $3^{\text {rd }}$ Ed. Lea \& Febiger, Philadelphia, 1975.

Solano P., Reifenberg J.M., Amsler-Delafosse S., Kabore I., CuISANCE D. \& Duvallet G. Trypanosome characterization by polymerase chain reaction in Glossina palpalis gambiensis and G. tachinoides from Burkina Faso. Medical and Veterinary Entomology, 1996, 10, 354-358.

Solano P., Koné A., Garcia A., Sané B., Michel V., Michel J.F., Coulibaly B., Jamonneau V., Kaba D., Dupont S. \& FourNET F. Rôle des déplacements des malades dans l'épidémiologie de la trypanosomose humaine africaine dans le foyer de Bonon, Côte d'Ivoire. Médecine Tropicale, 2003, $63,577-582$. 
Stanghellini A., Duvallet G. \& Brinckman U. Épidémiologie de la trypanosomiase humaine à Trypanosoma gambiense dans un foyer de Côte d'Ivoire. 1 - Distribution de la maladie dans la population. Tropical Medicine and Parasitology, 1981, 32, 141-144.

Vreysen M.J.B., Saleh K.M., Ali M.Y., Abdulla A., Zhu Z.R., Juma K.G., Dyck V.A., Msangi A.R., Mkonyi P.M. \& FeldMANN U. The use of the sterile insect technique (SIT) for the eradication of the tsetse fly Glossina austeni on the island of Unguja (Zanzibar). Journal of Economical Entomology, 2000, 93, 123-135.

VReysen M., Robinson A.S. \& Hendrichs J. Area wide control insect pests. Springer, Vienna, Austria, 2007, 789 p.

Reçu le 23 octobre 2007 Accepté le 6 octobre 2008 